\title{
Study Oxidative Stress Statues In Hypertension Women
}

Yasmeen Muhi Aldeen*

\section{Alaa H. Jawad"}

\author{
*Department of Chemistry, College of Sciences, Al Nahrain University, Baghdad, \\ Iraq \\ **Department of Chemistry, College of Sciences for Women, University of Baghdad \\ Baghdad, Iraq \\ E-mail: silversea5@ hotmail.com
}

Received 21/9/2015

Accepted 20/12/2015

(c) (1) (9)

This work is licensed under a Creative Commons Attribution-NonCommercial-

NoDerivatives 4.0 International Licens

\begin{abstract}
The oxidative stress is result of unbalancing between oxidants and antioxidants in the body. Hypertension (HT) is a measure of average systolic blood pressure which created by the heart contracting, greater $\geq 140 \mathrm{mmHg}$ or an average diastolic blood pressure, which is the heart fills, of $\geq$ equal to $90 \mathrm{mmHg}$. The study is conducted on 28 female patients with HT from Ibn Al-nafese hospital in addition to 28 female control. The markers measured are albumin, malondialdehyde (MDA) and 8-Hydroxy deoxyguanosine (8-OHdG). Also electrophoresis study on extracted DNA with Fenton reaction was done. Results of this study show there are high significant decrease $(\mathrm{p} \leq 0.01)$ in albumin concentration of patient related to control, and there is a high significant increase $(\mathrm{p} \leq 0.01)$ in each MDA and 8-OHdG for patients group in comparison with controls. The Fenton reaction done shows that oxidant has degradation effect on DNA either in two minutes of reaction. It is concluded that oxidative stress in its parameter (albumin) and markers (MDA and 8-OHdG) is main chemical manifestation of group under study. And oxidants produced by Fenton can denature the DNA in vitro.
\end{abstract}

Key words: Hypertension, Reactive oxygen species Malondialdehyde, 8-OHdG

\section{Introduction:}

Hypertension is defined as an average systolic blood pressure, which is created by the heart contracting, greater than or equal to140 $\mathrm{mmHg}$ or an average diastolic blood pressure, which is the heart fills, of greater than or equal to $90 \mathrm{mmHg}$ [1]. Hypertension is a disease and blood pressure is a biomarker [2] .
Reactive oxygen species (ROS) is a group term used for a group of oxidants, comprise both free radicals or molecular species capable of generating free radicals [3], such as hydrogen peroxide $\left(\mathrm{H}_{2} \mathrm{O}_{2}\right)$, superoxide $\left(\mathrm{O}_{2} \cdot-\right)$, and the hydroxyl radical $(\cdot \mathrm{OH})$. There are also reactive nitrogen, iron, copper, and sulfur species [4] which may initiate from exogenous sources like Cigarette, 
ozone, and asbestoses, and endogenous sources as products of important metabolic processes that are continuously going on in the body, e.g. electron transport chain in mitochondria, or Pathological Sources such as immune cell activation, inflammation, metabolism of environmental pollutants $\&$ certain drugs $[4,5]$

ROS are raise in hypertension in response to vessel stimulation by mechanical stretch or angiotensin II (AII)[6] . Reaction of ROS with endothelium released $\mathrm{NO}$, a gas is generated from the metabolism of Larginine by constitutive endothelial NO synthase, inhibits vasodilatory or antisclerotic effects of NO and thus can exacerbate the disease [7] .

Human body has complex system of defends antioxidant comprising enzymes such as reductse, some proteins or small-molecularweight compounds such as glutathione [8]. All of the above play a part in the redox balance. Whenever such equilibrium is disrupted, oxidative stress develops as a result of either excess oxidants production or inadequate antioxidant mechanisms, leading to plural oxidative modifications of basic and regulatory processes [5,9].

Malondialdehyde (MDA) [bis diethylacetal] $\mathrm{CHO}-\mathrm{CH} 2-\mathrm{CHO}$, is a dicarbonyl, with a molecular weight of 72 Daltons, formed as a secondary product of endoperoxide [10]. MDA is an end-product of the radical-initiated oxidative decomposition of polyunsaturated fatty acids; therefore, it is frequently used as a biomarker of oxidative stress [11]

8-Hydroxydeoxyguanosine (8$\mathrm{OHdG}$ ) is an oxidized nucleoside which is

excreted in the bodily fluids with DNA repair. $8-\mathrm{OHdG}$ is a most common stable product of oxidative DNA damage after enzymatic cleavage when ROS induced 8-hydroxylation of guanine base on nuclear and mitochondrial

DNA [12] and is considered a measure of DNA oxidation in response to free radicals [13]. The presence of this oxidized guanine in genomic DNA can cause transversion mutation such as G-T or G-A binding, accumulation of which can lead to detrimental consequences [14]

Albumin is a non-glycosylated protein of $66 \mathrm{kDa}$ [15]. Human serum albumin (HAS) shows antioxidant capability related to ligand-binding capacities HSA is well known for binding a large variety of molecules, including fatty acids, hormones, metal ions, and drugs [16]. It also has capacity to bind bilirubin and homocysteine by its one high affinity site [Lys240] for bilirubin [17]. The resulting HAS bound bilirubin acts as an inhibitor of lipid peroxidation and thus exemplifies an indirect antioxidant behaver of HAS $[16,17]$.

\section{Materials and Methods}

This study includes 28 female patients of age between 30-65 years referred to Ibn Alnafese hospital during the period from November 2013 to March 2014. The diagnosis of disease was made by physician with exclusion of presence of other diseases known to be associated with elevated oxidative stress [cancer, diabetes, arthritis, or cystic fibrosis] and vitamin supplements taken in the last 4 weeks. Patients were compared with age-matching group of 28 healthy control female subjects devoid of conditions like diabetes mellitus, epilepsy, psychiatric disorders or history of any drug intake and selected as control group. Ten milliliters were collected from each subject, Two and half milliliter of these blood samples were added into EDTA tubes and used for DNA extraction and remained blood was allowed to clot for at least 10-15 min. at room temperature, 
centrifuged for $10 \mathrm{~min}$. at $4000 \mathrm{rpm}$. The total serum MDA was measured by spectrophotometeric methods supplied by Shah and Walker by reaction with thiobarbituric acid (TBA) One molecule of MDA reacts with 2 molecules of Thiobarbituric acid [18].

\section{Estimation of Human 8-OHdG was performed according to the instruction of manufacture [Test Kit No.CSB-E10140h] produced by CUSABIO/China as the quantitative determination of endogenic human 8- $\mathrm{OHdG}$ concentration in the serum. The serum albumin was measured by kit supplied by Biosystem company.}

The statistical analysis were performed by SPSS [19]. The significance of difference between mean values was valued by using Student TTest. The probability $\mathrm{p} \leq 0.05=$ significant, $\mathrm{p}>0.05=$ non-significant and $\mathrm{p} \leq 0.01$ highly significant.

The DNA is isolated according to the ReliaPrep ${ }^{\text {TM }}$ gDNA Miniprep System [20] which provides a fast, simple technique for preparation of purified and intact DNA from mammalian. Samples are processed using a binding column in a micro centrifuge tube. The genomic DNA isolated is of high-quality and can be used in common applications such as Agarose gel analysis, restriction enzyme digestion and PCR analysis

The reaction with Fenton is done according to method of Wendy, reactions of [Fe[EDTA]II and $\mathrm{H}_{2} \mathrm{O}_{2}$ with DNA proceeded as follows: by adding $10 \mu \mathrm{L}$ of each $\mathrm{Fe}+{ }^{2} \mathrm{EDTA}$ solution, DNA[80 ng/ mL], phosphate buffer , $\mathrm{H}_{2} \mathrm{O}_{2}[0.3 \%]$ and sodium ascorbate and premixed on the inside wall of an eppendorf tube and then is directly added to the DNA solution and allowed to react for $2 \mathrm{~min}$. Reactions were stopped by addition of $100 \mu \mathrm{L}$ of a stop solution containing $10 \mathrm{mM}$ thiourea, 30 $\mathrm{mM}$ EDTA, and $0.6 \mathrm{mM}$ sodium acetate[21]. The reaction mixture was placed in $1 \%$ agarose gel for electrophoresis and run at $5 \mathrm{v} / \mathrm{cm}$ for $1 \mathrm{hr}$ according to Sambrook procedure[22] and screening done by Gel Documentation system, BioRad. USA.

\section{Results and Discussion:}

Eighty two patient subjects are included in this study and 28 apparently healthy individuals as control group.

Results of oxidative stress parameter show that is a highly significant in MDA concentration in patient group comparing with control group as shown in table 1. The significantly elevated $[p<0.01]$ in diagnosed hypertensive patient agree with (Dhananjay V. et al 2013)[23]. It has been demonstrated that increased intracellular generation of ROS plays an important role in chronic inflammatory responses to arterial diseases, so this causes damage to the membrane polyunsaturated fatty acids leading to the generation of MDA cause elevation in MDA in these patients [24].

The concentration of $8-\mathrm{OHdG}$ also shows a significant increase $[\mathrm{p}<0.01]$ in patient group relative to control, this result agrees with (Kaya y et al 2012 )[25] who found a significant difference in $8-\mathrm{OHdG}$ levels in hypertensive patient. Also (Fructaci et al 2015) [26] found an elevation in $8-\mathrm{OHdG}$ in cocaine related cardiomyopathy cases. This elevation may be due to the increased generation of ROS in certain type of white blood cells which contribute in reduction bioavailability of nitric oxide and thus to the endothelial dysfunction, as some of the hypertension-induced organ damage, which occurs due to hyperactivity of mechanisms that increase ROS production[25].

The concentration of albumin of patients shows significant decrease $(p<0.01)$ in patient serum relative to control group. This agrees with (Oda Eji et al 2012)[27]. The decrease in albumin 
The $2^{\text {nd }}$ National Conference of Chemistry

in patient may be due to its function as result of oxidative stress.

antioxidant activity that decrease as

Table (1): Results and Characteristics of samples

\begin{tabular}{|c|c|c|c|}
\hline Character & Patient group & Control group & p value \\
\hline Age $[$ year] & $46.8 \pm 8.2$ & $43.4 \pm 9.3$ & $>0.01$ \\
\hline BMI $\left[\mathrm{kg} / \mathrm{m}^{2}\right]$ & $31.48 \pm 0.95$ & $27.27 \pm 0.97$ & $>0.01$ \\
\hline $\mathrm{Hb}[\mathrm{g} / \mathrm{dL}]$ & $12.5 \pm 1.6$ & $12.00 \pm 1.36$ & $>0.01$ \\
\hline $\mathrm{MDA}[\mu \mathrm{mol} / \mathrm{L}]$ & $6.35 \pm 0.71$ & $3.31 \pm 0.26$ & $<0.01$ \\
\hline $8 \mathrm{OHdG}[\mathrm{ng} / \mathrm{mL}]$ & $105.43 \pm 28.94$ & $82.62 \pm 19.13$ & $<0.01$ \\
\hline Albumin $[\mathrm{g} / \mathrm{L}]$ & $35.52 \pm 1.84$ & $44.18 \pm 2.20$ & $<0.01$ \\
\hline
\end{tabular}

The integrity of isolated DNA was examined by electrophoresis:

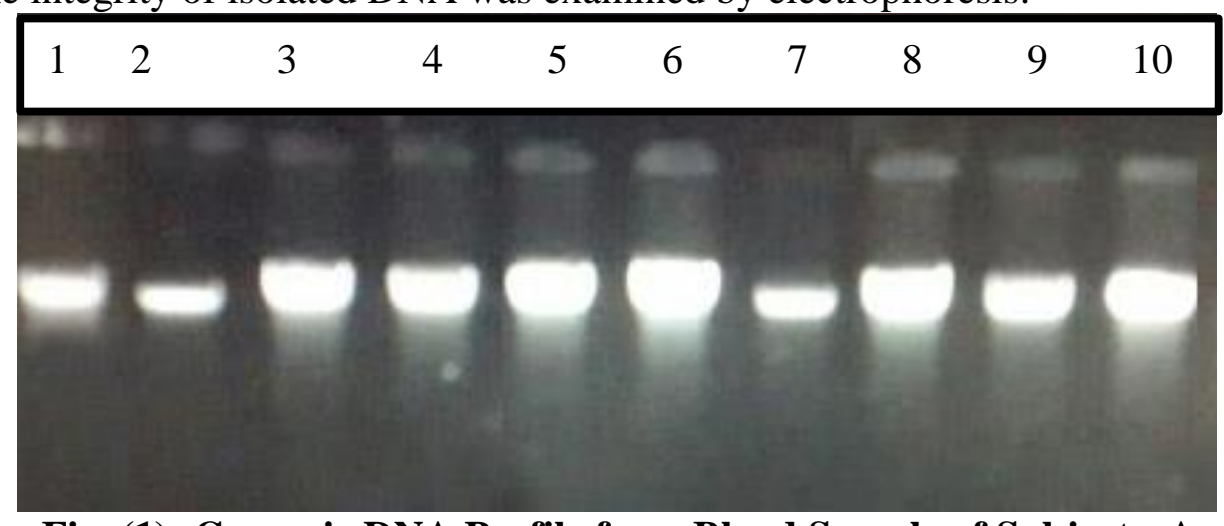

Fig. (1): Genomic DNA Profile from Blood Sample of Subjects, Agarose gel [1\%], 5 V/cm for $1 \mathrm{hr}$., Stained with Ethidium Bromide. Lane 1 placenta's DNA, lane 1-5 controls' DNA, lane 5-10 HTs' group DNA.

Reduction of $\mathrm{H}_{2} \mathrm{O}_{2}$ by reduced transition metals results in the formation of $\mathrm{OH}$ and related oxidants via the Fenton reaction [28].

$\mathrm{Fe}^{2+}+\mathrm{H}_{2} \mathrm{O}_{2}+\mathrm{H}^{+} \longrightarrow \mathrm{Fe}^{3+}+\mathrm{H}_{2} \mathrm{O}+\cdot \mathrm{OH}$

The produced hydroxide radical has been already done in vitro test tube experiments under Fenton's reaction conditions. $\mathrm{OH}$ has damaging effect on DNA, it may cause denaturation for double strands, mutation, as a means of inducing strand cleavage in DNA[29].

Using Fenton reaction to show oxidative stress effect on DNA, damaged of control's DNA was monitored by agarose gel electrophoresis and the result show this effect.

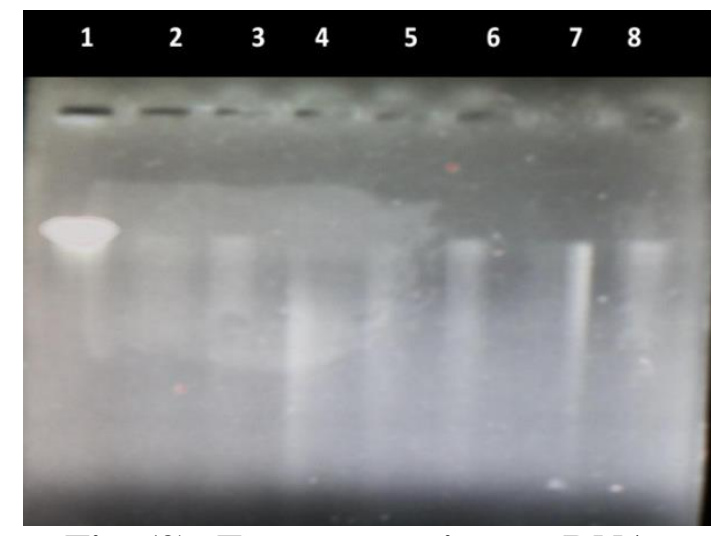

Fig. (2): Fenton reaction on DNA, lane 1: Control's DNA, lane 2-8: DNA with Fenton's reaction 2,4,6,8,10,12 and 14 mins

This result agree with (Plionical et al 2013) [30] who suggested high concentration of $\mathrm{H}_{2} \mathrm{O}_{2}$ that led to the degradation of all of major membrane proteins. 


\section{Conclusion:}

Oxidative stress in its markers and parameters is the main chemical manifestation of hypertension in the patients of underlying study. This conclusion was obvious in high significant difference between serum malondialdehyde, 8-OHdG and albumin in patients of hypertension. And oxidants produced by Fenton can denature the DNA in vitro.

\section{Acknowledgements}

The authors would like to thank AlNahrain University and Ibn- Alnafese hospital for the financial supports and research facilities

\section{References:}

[1] Giuseppe, M.; Fagard, R.; Narkiewicz, K.; Redán, J; Zanchetti, A.; Böhm, M.; Christiaens, T.; Cifkova, R.; De Backer, G.; Dominiczak, A.; Galderisi, M.; Grobbee, D.E.; Jaarsma, T.; Kirchof, P.; Kjeldsen, S.E.; Laurent, S.; Manolis, A.J.; Nilsson, P.M.; Ruilope, L.M.; Schmieder, R.E.; Sirnes, P.A.; Sleight, P.; Viigimaa, M. and Waeber, B. 2013. ESH/ESC Guidelines for the management of arterial hypertension: The Task Force for the management of arterial hypertension of the European Society of Hypertension (ESH) and of the European Society of Cardiology (ESC). EUR HEART J, 34 (28): 2159-219.

[2] Thomas, D. 2014. Hypertension : the place to start. J Clin Hypertens, 16(1), 4-5.

[3] Balarman, K. 2013. Teaching the basics of redox biology to medical and graduate students: Oxidants, antioxidants and disease mechanisms, a graphical review:. J Red Biol, 1(1): 244-257.

[4] Poljsak, D.; Dusan, S and Irina, M. 2013. Achieving the Balance between ROS and Antioxidants: When to Use the Synthetic Antioxidants, Review Article. J Oxi Med Cell Longev, 20(13), 11 pages

[5] Noori, S. 2012. An Overview of Oxidative Stress and Antioxidant Defensive System. Open Access Sci Rep, 1(8), 1-8.

[6] Ahmad, A; Singhal, U.; Mohd, M.; Islam, N. and Rizvi, I. 2013. The Role of the Endogenous Antioxidant Enzymes and Malondialdehyde in Essential Hypertension. J Clin Diagnostic Res., 7(6), 987-990.

[7] Steven, D. 2014. The Cooperative Roles of Inflammation and Oxidative Stress in the Pathogenesis of Hypertension. Antioxi and Red Sig, 20(1), 102-120.

[8] Kunwarm A. and Priyadarsini K. 2012. Free radicals, oxidative stress and importance of antioxidants in human health. $\mathrm{J}$ of Med. and Allied Sci, 1(2), 53-60.

[9] Sies, H. 2015. Oxidative stress: a concept in redox biology and medicin, Mini Review. Redox Biology 4(1), 180-183.

[10] Nagamani, P.; Vijayababu, P.; Ashalata, K. P. Kusuma, K. and Lakshmi, K. 2015. Lipid Peroxidation Product as a Marker Of Oxidative Stress In Psoriasis -A Case Control Study In North Coastal Andhra Pradesh. J of Dent and Med Sci, 14(5) : 18-20.

[11] Cipierre, C.; Stéphane, H.; Boulch. D.; Paul, S. and Picaud, J. 2013. Malondialdehyde Adduct to Hemoglobin: A New Marker of Oxidative Stress Suitable for FullTerm and Preterm Neonates. Oxid Med Cell Longev., 6 pages

[12] Arunima, P.; Rajeev, R.; Kurra, V.; Mohan, S.B. and Mohan R. 2014. Salivary 8

Hydroxydeoxyguanosine- a valuable indicator for oxidative DNA damage in periodontal disease. The Saudi J Dental Research, 2(3): 1-6 
[13] Ibrahim, A. and Saleh, D. 2014. DNA Damage in Lung Cancer Patients and Control Iraqi Subjects Using Elisa Technique. Int J Biol \& Pharmacological research, 5(8): 627629

[14] Kim, E.; Young, C.; Choi, D.; Lee, H.; Hahm, K. and Hee, C. 2012. 8Hydroxydeoxyguanosine: Not mere biomarker for oxidative stress, but remedy for oxidative stressimplicated gastrointestinal diseases. World J Gastr, 18(4), 302-308.

[15] Quinlan, G.; Martin, G. and Evans, T. 2005. Albumin: Biochemical Properties and Therapeutic Potential., Hepatology, 41(6): 1211-1219

[16] Taverna, M.; Anne, L.; Jean, P.; and Bertrand, G. 2013. Specific antioxidant properties of human serum albumin. Annals of Intensive Care, 3(4):7 pages.

[17] Marjolaine, R.; Philippe, R.; Nihar, R.; Evelyne, T. and Emmanuel, B. 2008. The antioxidant properties of serum albumin, Mini review, Fed Eur Bioch Soci, 582(1), 1783-1787.

[18] Shah, S. and Walker, P. 1988. Evidence suggesting a role for hydroxyl radical in glycerol-induced acute renal failure. Am J Physiol., 255 (2):438-443

[19] Cary, N. 2012. Statistical Analysis System, User's Guide. Statistical. Version $9.1^{\text {th }}$ ed. SAS. Inst. Inc. USA

[20] Hook, B.; Vincent, E. and Schagat, T. 2011. ReliaPrep ${ }^{\mathrm{TM}}$ Blood gDNA Miniprep System: Low Elution Volume with High Yield. Promega Company. Website.

[21]Wendy, J.; Timothy, M. and Thomas, D. 1995. What Species Is Responsible for Strand Scission in the Reaction of (FeEDTA) $)^{2-}$ and $\mathrm{H}_{2} \mathrm{O}_{2}$ with DNA?. J Am. Chem., 117(24): 6428-6433.

[22] Sambrook, E.; Fritsch, F. and Maniatis, T. 1989. Molecular cloning: A laboratory manual: 2nd ed. Edited by J. Cold Spring Harbor Laboratory Press, Cold Spring Harbor, New York.

[23] Dhananjay V., Manjusha D., Roshan K., Aasiya S., Devendra M. and Ashlesha B. 2013. Study of Oxidative Stress in Patients with Hypertension. Inter. J of R. Trends in Sci. And Tech., 9(1): 157-158.

[24] Hasan, R.; Ahmad, M.; Aisha, J. and Zaka, F. 2013. A study on the variations in lipid profile of valvular heart disease patients. Int $\mathbf{J}$ Biol Med Res, 4(3): 3414-3418

[25] Kaya,Y.; Ayşegül, C.; Nihat, S.; Halit, D.; Hamit, H. and Ebubekir, B. 2012. Correlations between Oxidative DNA Damage, Oxidative Stress and Coenzyme Q10 in Patients with Coronary Artery Disease. Int J of Med Sci, 9(8), 621-626

[26] Frustaci, A. and Matteo, A. 2015. Oxidative myocardial damage in human cocaine-related cardiomyopathy, Eur J of Heart Fail, 17(3), 283-290.

[27] Oda, E. 2012. Decreased serum albumin predicts hypertension in a Japanese health screening population . Intern Med., 53(7):655-660

[28] Kelly, M. 2008. Analysis of Oxidative Damage to DNA Mediated by Transition Metal-Fenton Reactions, Thesis PhD, Dublin City University, 235 pages.

[29] Thomas, B.; Anastassiya, B.; Polycarpos, P. and Alexandros, G. 2011. Role of oxidative stress and DNA damage in human carcinogenesis a Review. Mutat Res, 711(1), 193-201.

[30] Pleonsil, P. and Suwanwong, P. 2013. An in vitro study of cphycocyanin activity on protection of DNA and human erythrocyte membrane from oxidative damage. $\mathbf{J}$ of Chem and Pharmaceutical Res, 5(5):332-336. 


\section{دراسة مستويات الاجهاد التأكسدي عند المريضات بارتفاع ضغط الدم \\ بري حبن

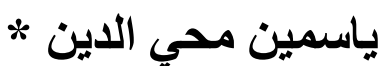 \\ علاء حسين جواد * ت ع}

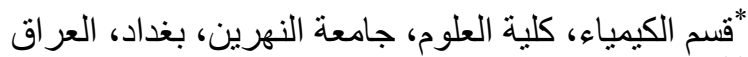

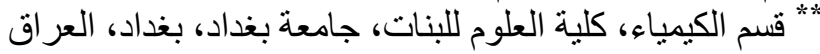

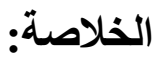

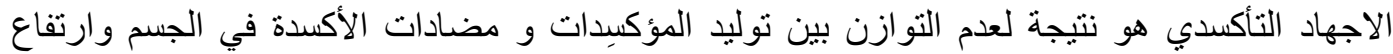

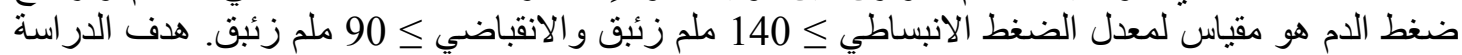

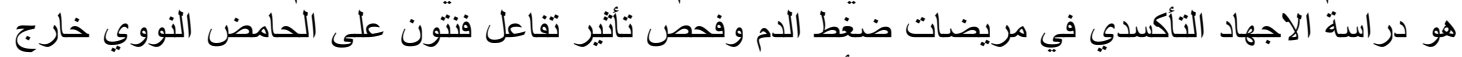

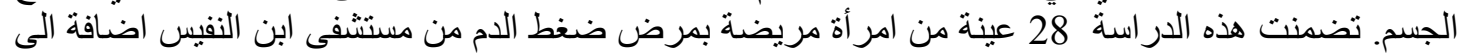

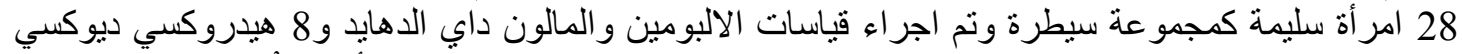

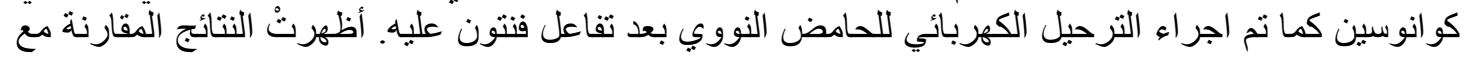

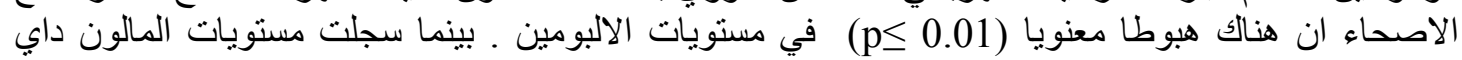

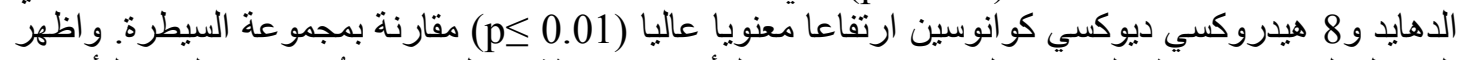

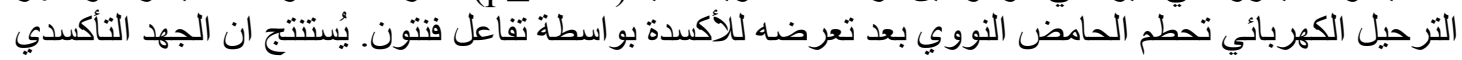

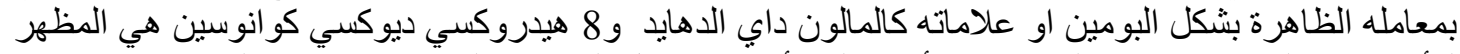

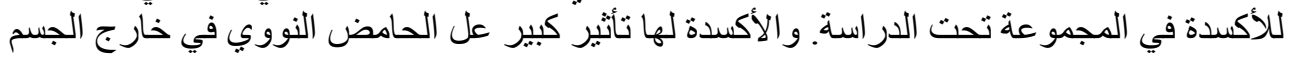

الكلمات المفتاحية : ارتفاع ضغط الدم، أصناف الاوكسجين الفعالة، المالون داي الدهايد، 8-هيدروكسي ديوكسي كو انوسين 